\title{
Hyvän suunnittelun muuttuvat periaatteet
}

Jonne Hytönen

Kirjoitus perustuu Oulun yliopistossa 9.11.2019 järjestetyn väitöstilaisuuden lektioon.

Valtion keskushallinnon kaavoitusvaltaa purettiin Suomessa vuosituhannen vaihteessa. Paikallishallinnolle, kansalaisyhteiskunnalle ja toisaalta vapaalle markkinakilpailulle haluttiin alue- ja yhdyskuntasuunnittelussa uutta joustavaa tilaa.

Aiemmin, 1980- ja 1990-lukujen myötä, alueiden suunnittelussa oli ilmennyt uusia haasteita. Pohjois- ja Itä-Suomen vesivoimaan ja teollisuuslaitoksiin liittynyt asuinrakentamisen aikakausi oli hiipunut. Kaupungeissa siirryttiin aluerakentamisesta täydennysrakentamiseen, joten rakennus- ja kaavahankkeiden järkevyydestä piti saada vakuuttuneeksi kokonaan uudenlaisia osallisryhmiä. Esimerkiksi Hanna Mattila (2017) on kuvannut tarvetta vuorovaikutukselle täydennettävillä alueilla jo asuneiden yhteisöjen kanssa.

Suunnitteluteoreetikkojen kiinnostus kohdistui kansalaisyhteiskunnan ja byrokraattiseksi koetun julkisen suunnitteluapparaatin väliseen suhteeseen - ei niinkään markkinatoimijoiden ja julkisen sääntelyn suhteeseen. Tutkijat kannustivat julkisia toimijoita ottamaan kuntalaiset mukaan maankäytön suunnitteluun. Lainsäätäjä vastasi huutoon. Matti Vatilon (20oo) sanoin haluttiin siirtyä "Käskyvallasta kumppanuuden aikaan".

Kansainväliset esimerkit, joiden ytimessä oli suunnittelijan vallan jakaminen, inspiroivat suomalaisia kirjoittajia. Esimerkiksi Englannissa vahvasti keskushallintovetoista suunnittelua oli jo aiemmin alettu purkaa. Heikossa asemassa olevien paikallisyhteisöjen voimaannuttaminen, silloin kun vastassa oli ylikorostunut taloudellinen valta, oli painotuksena erityisesti amerikkalaisessa suunnitteluteoriassa. Ankaran epäröivä suhtautuminen julkiseen valtaan loi otollisen maaperän suunnitteluhallinnon läpinäkyvyyttä painottavalle näkemykselle. Suunnitteluinstituutioon - oli se sitten yksityinen tai julkisella 
valtuutuksella toimiva - ei angloamerikkalaisessa maailmassa kohdistunut aina kovinkaan vahvaa luottamusta.

Sama katsanto omaksuttiin jokseenkin suoraviivaisesti myös Suomeen. Suunnittelijoiden pyrkimyksiin määrittää sitä, mitä yleinen etu piti sisällään, suhtauduttiin korostetun epäilevästi. Kriittisestä tieteenperinteestä ammentaen käsite otettiin suurennuslasin alle. Usein ajateltiin aivan perustellusti, että yleisestä edusta puhuvat ne, jotka itse asiassa haluavat edistää omaa kapeaa intressiään yleisen edun nimissä.

Jotta suunnitteluratkaisut voitiin läpivalaista kerta toisensa jälkeen, vuorovaikutuksen merkitys paikallisissa konteksteissa korostui. Samanaikaisesti erityisesti keskushallinnon mahdollisuuksia kontrolloida maankäyttöä kavennettiin. Kuntien ei esimerkiksi enää tarvinnut lähettää kaavaratkaisujaan hyväksyttäväksi ministeriöön. Suuntaus on jatkunut aivan viime vuosiin saakka, joten kunnilla on runsaasti liikkumavaraa päättäessään millaista suunnittelua ne haluavat omien voimavarojensa puitteissa edistää.

\section{Vaade joustavuudesta}

Väitöskirjassani kuvaan suunnittelukulttuurin muutosta ja paikallisen vallan kasvattamista suunnittelu- ja valtioteoreettisista näkökulmista. Väitän, että kuntien liikkumavaraa kasvatettaessa keskustelu suunnittelun suurista linjoista on hiipunut. Poliittista harkintavaltaa on hajautettu ja kuntien valtaa suhteessa valtion keskushallintoon korostettu, mikä ei ole kestävyyden tai demokratian näkökulmasta ongelmaton kehityskulku. Lainsäädäntö mahdollistaa kuntien kaavoituksen kehittämisen ympäristöarvot huomioivaan suuntaan, velvoittamisen sijaan.

Kaavoituksen hankkeita mahdollistavaa luonnetta on vahvistettu kaupungistuvan kasvun nopeuttamiseksi. Suunnitteluteoreettinen keskustelu on pitkään keskittynyt suunnittelijoiden ja kansalaisyhteiskunnan väliseen suhteeseen tavalla, joka on vienyt käsitykseni mukaan kuin huomaamatta huomiota yksityisten markkinatoimijoiden ja julkisen sääntelyn välisestä suhteesta.

Niin sanotun kommunikatiivisen suunnitteluteorian suosituksiin sopeutumalla suunnittelujärjestelmän joustavuutta on lisätty. Nopeasti kärjistyvän ympäristökriisin alla olisi kuitenkin entistä tärkeämpää arvioida erilaisia yksityiskohtaisen suunnittelun hankkeita suhteessa asetettuihin demokraattisuusja kestävyystavoitteisiin. Väärällä tavalla lisättyyn suunnittelun joustavuuteen sisältyy lyhytjänteisen markkinareaktiivisuuden riski.

Suunnittelujärjestelmän muutosta voi lähestyä myös valtioteoreettisesti. Kyseenalaistan väitöskirjassani oletuksen, jonka mukaan harkinta erilaisten kaavoitusratkaisujen välillä tulee tuoda mahdollisimman lähelle paikallista 
tasoa. Kaavoitukselle on luotu demokraattisessa järjestyksessä tavoitteet ja oikeudelliset pelisäännöt, joista joustaminen paikallisesti vaikutusvaltaisten intressien paineen alla ei mitenkään välttämättä edistä kestävyyttä tai suunnittelun oikeudenmukaisuutta.

Yhdyskuntapolitiikka ja erilaiset elinvoimatehtävät ovat jatkossa kuntapäättäjien tehtävien ytimessä, sillä kuntien valta sosiaali- ja terveydenhuollossa kaventunee. Nähtäväksi jää, millä tavoin kasvava kiinnostus kaavoitusta kohtaan kanavoituu kuntien tekemissä ratkaisuissa ja kyetäänkö verotulojen houkutteluun liittyviä ylilyöntejä välttämään. Kaupunkiseuduilla yhdyskuntapoliittisia valintoja ehdollistaa myös jatkossa kunnan etu - siitä huolimatta, että kuntien välisen osaoptimoinnin ja kilpailun ongelma on ollut tiedossa pitkään. Kaupunkiseutujen ulkopuolella ja harvaan asutuilla alueilla olisi kyettävä esimerkiksi suurten luonnonvara- ja matkailuhankkeiden ohjaamiseen ja sääntelyyn.

Kunnilla on vastuu kustannuksista, joita yhdyskuntapoliittisesta päätöksenteosta seuraa. Demokraattisesti ohjatuissa kunnissa on ymmärrystä paikallisista olosuhteista ja tarpeista. Kuntien itsehallintoa kaavoituksessa tukevat siis monet seikat. Lainsäädäntö kuitenkin rajaa aina paikallista itsehallintoa, jota tulisi toteuttaa hyvän hallinnon periaatteiden ja laillisuusperiaatteen puitteissa. Edellytyksiä pitkäjänteiseen suunnitteluun ei aina ole, ja on huomionarvoista, ettei näin ole aina suurissakaan kunnissa.

Tiukan julkisen talouden tilanteessa kuntien edellytykset toimia uskottavina kestävän suunnittelun edistäjinä vaihtelevat väistämättä. Mikäli hyvän suunnittelun periaatteista keskustellaan vain paikallisissa puitteissa, laajat ja kaikkein kollektiivisimmat näkökulmat voivat jäädä vähälle huomiolle. Ilman riittävän sääntelyvoimaista ja legitiimiä suunnitteluapparaattia on entistä vaikeampaa varmistua siitä, että ympäristönäkökulmat tai kaupunkiseutujen sisäisen eriytymisen ongelmat kyetään ottamaan huomioon.

\section{Vaade kestävyydestä}

Puolustan väitöskirjassani demokraattisesti ohjattua suunnittelukoneistoa ja sen toimintakyvyn suojelemista. Kyse on kansanvaltaisesta pääomasta ja ainakin verrattain legitiimistä mahdollisuudesta ohjata yhdyskuntakehitystä tavalla, jossa kollektiiviset ja ympäristölliset tavoitteet olisivat ensisijaisia.

Kaavoituslain uudistamisen ensimmäiset askelmerkit perustuivat toisenlaiseen ymmärrykseen julkisesta suunnittelusta. Niiden taustalla on näkemys kaavahierarkian kömpelyydestä ja rajoittavuudesta. Vuonna 2018 vuonna räjähdysmäisesti lisääntyneen ilmastopoliittisen keskustelun näkökulmasta uudistuksen norminpurkuun nojaavat lähtökohdat näyttäytyvät kuitenkin jo nyt uudessa valossa. 
Ymmärrys kaupungistuvan kasvun ja siihen liittyvän vaurastumisen kytköksistä luonnonvarojen ylikulutukseen on lisääntynyt merkittävästi. Niin sanottu kriittisen kestävyyden näkökulma kyseenalaistaa ajatuksen, jonka mukaan taloudellinen kasvu voisi ylipäätään olla kestävää. Mikäli ympäristön asettamiin reunaehtoihin suhtaudutaan vakavasti, erilaisiin hankkeisiin joudutaan jatkossa suhtautumaan ennen kaikkea valikoiden, ei vain fasilitoiden. Suunnittelun luonne muuttuu.

Ilmastonmuutoksen, luonnon monimuotoisuuden vähenemisen ja yhteiskunnallisen polarisaation kaltaiset kehityskulut haastavat yhdyskuntien kehitystä mahdollisesti jo lähivuosina aivan uudella tavalla. Jotta voimme reagoida näihin kehityskulkuihin, tarvitsemme luotettua ja oikeudenmukaista maankäytön suunnittelujärjestelmää. Kommunikatiiviselle lähestymistavalle - siltä osin kuin se suosittaa tiukasti paikallisiin näkökulmiin rajautumista - uudenlainen, kriittisen kestävyyden varaan rakentuva suunnittelukulttuuri on haaste. Jännitteisyys yksityisen ja yleisen edun väliltä ei ole hävinnyt, vaikka siihen on kiinnitetty jo pitkään suunnitteluntutkimuksessa aiempaa vähemmän huomiota.

Läpinäkyvyyttä ja vuorovaikutteisuutta tarvitaan, sillä julkista suunnitteluapparaattia kohtaan koettu luottamus tulee olemaan koetuksella talouskasvun haitallisia vaikutuksia hillittäessä. Vuorovaikutuksesta kumpuava luottamus ei kuitenkaan ole poissulkeva vaihtoehto luottamukselle, jota edustuksellisen demokratian periaattein ohjattuja suunnittelun instituutioita kohtaan koetaan. Julkinen suunnittelukoneisto on toisin sanoen toimintakykyisempi, jos se etsii vahvistusta myös vuorovaikutteisuudesta ja avoimuudesta. Suunnittelun vuorovaikutteisuutta ei ole välttämätöntä nähdä urbaanin kasvun sujuvoittamisen välineenä, vaan kasvun kriittisen arvioinnin kollektiivisena alustana.

Kunnissa toimivat kaavoituksen viranomaiset ovat pitkään hoitaneet sääntelyja valvontatehtävää verrattain uskottavasti kasvun mahdollistamisen rinnalla. Viranhaltijat ovat kuitenkin jatkuvan paineen alla, sillä kunnat ovat väistämättä riippuvaisia verotuloista ja työpaikoista. Keskustelua hyvän suunnittelun periaatteista määrittelee yhä enemmän kuntien ja kaupunkiseutujen kilpailukyky. Elinkeinoelämän hankkeiden korostuneen lyhytjänteinen edistäminen ei edistä kuntien uskottavuutta osana tulevaisuuteen suuntautunutta julkishallintoa.

KIRJALLISUUS

Mattila, H. (2017). Revisiting Habermas. Exploring the Theoretical Roots and Contemporary Challenges of Communicative Urban and Regional Planning. Aalto University publication series. Doctoral dissertations 91/2017. Unigrafia Oy, Helsinki.

Vatilo, M. (2000). Käskyvallasta kumppanuuden aikaan - Reunamerkintöjä Kaj Nymanin puheenvuoroon. Yhdyskuntasuunnittelu, 38(2), ss. 17-24. 